\section{Australian Journal of \\ Crop Science}

\title{
Morpho-physiology and oil yield of castor bean (Ricinus communis L.) as a function of salinity and the cationic nature of irrigation water
}

\author{
Geovani Soares de Lima $^{1 *}$, Hans Raj Gheyi ${ }^{2,4}$, Reginaldo Gomes Nobre ${ }^{3,5}$, Diego Azevedo Xavier ${ }^{1}$, \\ Lauriane Almeida dos Anjos Soares ${ }^{1}$ and Jônatas Raulino Marques de Sousa ${ }^{1}$
}

${ }^{1}$ Federal University of Campina Grande, Academic Unit of Agricultural Engineering, Campina Grande, 58.109970, Paraíba, Brazil

${ }^{2}$ Federal University of Recôncavo of Bahia, Nucleus of Soil and Water Engineering, Cruz das Almas, 44.380-000, Bahia, Brazil

${ }^{3}$ Federal University of Campina Grande, Academic Unit of Agricultural Science, Pombal, 58.840-000, Paraíba, Brazil

${ }^{4}$ Fellow of CNPq Reseach Productivity, level 1A, Brazil

${ }^{5}$ Fellow of CNPq Research Productivity, level 2, Brazil

*Corresponding author: geovanisoareslima@gmail.com

\begin{abstract}
This study aimed to evaluate the morpho-physiology and oil yield of castor bean (cultivar 'BRS Energia') as a function of irrigation water salinity and cationic nature. The experiment was carried out using an Ultisol of sandy loam texture, in Campina Grande, Paraíba, Brazil. Six combinations of cations and water electrical conductivity (ECw) were studied $\left(\mathrm{S}_{1}-\mathrm{Control} ; \mathrm{S}_{2}-\mathrm{Na}^{+} ; \mathrm{S}_{3}-\mathrm{Ca}^{2+}\right.$; $\mathrm{S}_{4}-\mathrm{Na}^{+}+\mathrm{Ca}^{2+} ; \mathrm{S}_{5}-\mathrm{K}^{+}$and $\left.\mathrm{S}_{6}-\mathrm{Na}^{+}+\mathrm{Ca}^{2+}+\mathrm{Mg}^{2+}\right)$, in a randomized block design, with four replicates and five plants in each plot. Plants in the control treatment $\left(\mathrm{S}_{1}\right)$ were irrigated using water of $0.6 \mathrm{dS} \mathrm{m}^{-1}$, while the other treatments were irrigated using water of $4.5 \mathrm{dS} \mathrm{m}^{-1}$, prepared using chloride salts of different cations. Gas exchanges, growth and oil yield of castor bean were more affected by $\mathrm{ECw}$ variation than by the cationic nature of the water. Among the tested cations, potassium promoted the highest values of gas exchange and growth except in the flowering and fruiting stages. Oil yield is the most sensitive variable to the cationic nature of irrigation water.
\end{abstract}

Keywords: irrigation, Ricinus communis L., salinity.

Abbreviations: $A_{-} \mathrm{CO}_{2}$ assimilation rate; $\mathrm{AW} \_$available water; $\mathrm{Ci}$ _internal $\mathrm{CO}_{2}$ concentration; DAS_ days after sowing; $E_{-}$transpiration; ECW_electrical conductivity of water; EICI_ instantaneous carboxylation efficiency; $g s_{-}$stomatal conductance; LA_leaf area; NL_number of leaves; OC_oil content; OM_organic matter; OY_oil yield; PH_plant height; SAR_sodium adsorption ratio; SD_stem diameter; SL_sandy loam; WUE_intrinsic water use efficiency.

Introduction

Castor bean (Ricinus communis L.) belongs to the Euphorbiaceae family, with potential for economic exploitation in the northeast region of Brazil, due to its xerophilic and heliophilic characteristics. It is an oil seed crop of significant socioeconomic value, with products and byproducts used in castor oil industry and agriculture (Ribeiro et al., 2009). Its oil, or ricin, extracted by seed pressing, contains $90 \%$ of ricinoleic fatty acid, which gives it singular characteristics, allowing wide industrial use (Amorim Neto et al., 2001). Under adverse climatic conditions, especially in the semiarid regions, high temperatures, low rainfall, irregular distribution of rains and intense evaporation are common in most months of the year, and irrigation is the best way to guarantee agricultural production (Nobre et al., 2011). However, the composition of the water available in this region varies depending on the total salt concentration, local geology and type of the water source, and waters rich in sodium, calcium, magnesium and, in some cases, potassium are commonly found (Medeiros et al., 2003).
The use of water and/or soils with salt problems can limit crop growth and production due to the reduction of the osmotic potential of the soil solution, which can also cause ion toxicity, nutritional imbalance or both, because of the excessive accumulation of certain ions in plant tissues, especially chloride and sodium (Flowers, 2004). However, the use of these waters in irrigation depends on certain factors, including salt type and concentration, exposure time, crop phenological stage, edaphoclimatic factors and the interaction between them (Ashraf and Harris, 2004).

Quantitative and qualitative depletion of water resources have led to the search for alternatives for a more efficient use of water and the rational use of the commonly called lowquality waters, since the use of saline water in agriculture is almost mandatory in semiarid regions (Alves et al., 2011). Thus, many authors have studied the effects of irrigation water with different salinity levels on the cultivation of castor bean (Campos et al., 2009; Soares et al., 2012; Alves et al., 2012; Nobre et al., 2013; Santos et al., 2013; Lima et al., 
2014a); however, information on the effect of water with different cationic nature is still scarce.

Since most crops cultivated in the region are classified as sensitive to moderately sensitive to salinity, there arises the need for characterizing these waters, in order to establish an adequate management of crop, soil and irrigation systems (Medeiros et al., 2003), especially for the castor bean cultivar 'BRS Energia'. Thus, it becomes imperative to develop new studies on the effects of different types of cations in the irrigation water on castor bean, under the conditions of the semiarid region in Brazil. In this context, the morphophysiology and oil yield of the castor bean cultivar 'BRS Energia' were evaluated as a function of irrigation water salinity and cationic nature.

\section{Results and Discussion}

\section{Effect of irrigation water salinity and cationic nature on castor bean physiology}

According to the F test (Table 1), there was significant effect of water salinity on stomatal conductance, transpiration, internal $\mathrm{CO}_{2}$ concentration, $\mathrm{CO}_{2}$ assimilation rate, intrinsic water use efficiency and instantaneous carboxylation efficiency of castor bean. According to the comparison of means for stomatal conductance $(g s)$ (Fig 1A), there was significant difference between the treatments, and plants irrigated with low-salinity water (Control) and water containing $\mathrm{K}\left(\mathrm{S}_{5}\right)$ were statistically superior to plants in the $\mathrm{S}_{2}$ treatment, while plants in the treatments $\mathrm{S}_{1}, \mathrm{~S}_{3}, \mathrm{~S}_{4}, \mathrm{~S}_{5}$ and $\mathrm{S}_{6}$ did not differ statistically. The lowest $g s$ values were observed in plants irrigated with water containing $\mathrm{Na}\left(\mathrm{S}_{2}\right)$. There was significant difference for $g_{s}$ (Table 1) in the contrasts of $\mathrm{S}_{1} v s$ the other treatments $\left(\mathrm{S}_{2} ; \mathrm{S}_{3} ; \mathrm{S}_{4} ; \mathrm{S}_{5}\right.$ and $\left.\mathrm{S}_{6}\right)$, $\mathrm{S}_{2} v s \mathrm{~S}_{5}$ and $\mathrm{S}_{5} v s$ the other salts $\left(\mathrm{S}_{2} ; \mathrm{S}_{3} ; \mathrm{S}_{4}\right.$ and $\left.\mathrm{S}_{6}\right)$. According to the estimate of the means (Table 1), plants irrigated with water of $\mathrm{ECw}=0.6 \mathrm{dS} \mathrm{m}^{-1}$ showed an increase of $0.09 \mathrm{~mol}$ of $\mathrm{H}_{2} \mathrm{O} \mathrm{m}^{-2} \mathrm{~s}^{-1}$ for $g s$, compared with plants under high salinity water $-\mathrm{ECw}=4.5 \mathrm{dS} \mathrm{m}^{-1}\left(\mathrm{~S}_{2} ; \mathrm{S}_{3} ; \mathrm{S}_{4} ; \mathrm{S}_{5}\right.$ and $\left.\mathrm{S}_{6}\right)$. Such decrease of $g s$ in the treatments under the highest saline level can be related to the change in the osmotic potential and, consequently, to the reduction of water availability in plant tissues. Thus, possibly there was stomatal closure and a consequent reduction of the normal $\mathrm{CO}_{2}$ flow towards the carboxylation site (Tezara et al., 2005).

When water containing $\mathrm{Na}$ was used in the irrigation $\left(\mathrm{S}_{2}\right)$, gs decreased by $0.13 \mathrm{~mol}$ of $\mathrm{H}_{2} \mathrm{O} \mathrm{m}^{-2} \mathrm{~s}^{-1}$, compared with the treatment $S_{5}(K)$. In the comparison between $S_{5}$ and the other treatments, at the same level of ECw $\left(\mathrm{S}_{2} ; \mathrm{S}_{3} ; \mathrm{S}_{4}\right.$ and $\left.\mathrm{S}_{6}\right)$, gs increased by $0.10 \mathrm{~mol}$ of $\mathrm{H}_{2} \mathrm{O} \mathrm{m}^{-2} \mathrm{~s}^{-1}$. The lowest decrease in $g s$ (Fig $1 \mathrm{~A}$ ) when plants were irrigated with water containing $\mathrm{K}$, in relation to the other types of saline waters, can be associated with the functions of $\mathrm{K}^{+}$in plant metabolism, since this macronutrient participates in the maintenance of the ionic equilibrium and cell turgor, through the control of stomatal opening and closure (Gurgel et al., 2010). As observed for $g s$, leaf transpiration $(E)$ also differed statistically as a function of the types of salts in the irrigation water (Fig 1B), especially in the treatments Control and $\mathrm{S}_{5}$, with the highest mean values of $E\left(2.72\right.$ and $2.69 \mathrm{mmol}$ of $\mathrm{H}_{2} \mathrm{O} \mathrm{m} \mathrm{m}^{-2} \mathrm{~s}^{-1}$, respectively). However, the treatments $S_{1}, S_{3}, S_{4}, S_{5}$ and $S_{6}$ did not differ with respect to $E$. According to the estimate of the mean for $E$ (Table 1), there was an increase of $0.53 \mathrm{mmol}$ of $\mathrm{H}_{2} \mathrm{O} \mathrm{m}^{-2} \mathrm{~s}^{-1}$ when plants irrigated with waters of $0.6 \mathrm{dS} \mathrm{m}^{-1}$ and $4.5 \mathrm{dS} \mathrm{m}^{-1}$ were compared. On the other hand, the $\mathrm{S}_{2}$ treatment significantly affected $E$, showing a decrease of 0.54 mmol of $\mathrm{H}_{2} \mathrm{O} \mathrm{m}^{-2} \mathrm{~s}^{-1}$ when compared to $\mathrm{S}_{6}$ (Table 1 ).
However, in the contrast $\mathrm{S}_{2}$ vs $\mathrm{S}_{5}, E$ was significantly influenced and decreased by $0.88 \mathrm{mmol}$ of $\mathrm{H}_{2} \mathrm{O} \mathrm{m}^{-2} \mathrm{~s}^{-1}$ in $\mathrm{S}_{2}$. In addition, the transpiration of plants in the $\mathrm{S}_{5}$ treatment was significantly affected, compared with $\mathrm{S}_{2}, \mathrm{~S}_{3}, \mathrm{~S}_{4}$ and $\mathrm{S}_{6}$, and showed an increase of $0.62 \mathrm{mmol}$ of $\mathrm{H}_{2} \mathrm{O} \mathrm{m}^{-2} \mathrm{~s}^{-1}$ (Table 1).

The reduction of $E$ in the treatments $\mathrm{S}_{2}, \mathrm{~S}_{3}, \mathrm{~S}_{4}$ and $\mathrm{S}_{6}$ (Fig 1B) is mainly due to the partial stomatal closure (Fig 1A), a strategy of plants to avoid excessive dehydration of guard cells or a consequence of water imbalance on the leaf epidermis, a mechanism that leads to the decrease of $\mathrm{CO}_{2}$ diffusion and, consequently, the reduction of the $\mathrm{CO}_{2}$ assimilation rate (Ribeiro et al., 2009, Machado et al., 2010).

As to the internal $\mathrm{CO}_{2}$ concentration $(\mathrm{Ci})$, the highest values were observed in plants under $S_{2}, S_{3}, S_{4}$ and $S_{6}$ treatments, which were statistically higher than those observed in plants of $S_{1}$ and $S_{5}$, according to the test of comparison of means (Fig 2A). Castor bean plants irrigated with low-salinity water $\left(0.6 \mathrm{dS} \mathrm{m}^{-1}\right)$ showed decrease of $72.71 \mu \mathrm{mol} \mathrm{m}^{-2} \mathrm{~s}^{-1}$ in $\mathrm{Ci}$, compared with those receiving water of $4.5 \mathrm{dS} \mathrm{m}^{-1}\left(\mathrm{~S}_{2} ; \mathrm{S}_{3} ; \mathrm{S}_{4}\right.$; $\mathrm{S}_{5}$ and $\mathrm{S}_{6}$ ); while plants irrigated with water containing $\mathrm{Na}$ $\left(\mathrm{S}_{2}\right)$ increased Ci by $33.81 \mu \mathrm{mol} \mathrm{m} \mathrm{m}^{-2} \mathrm{~s}^{-1}$ when compared with those under $\mathrm{S}_{3}$ (Table 1). Similarly, Ci increased by 30.18 $\mu \mathrm{mol} \mathrm{m} \mathrm{m}^{-2} \mathrm{~s}^{-1}$ in $\mathrm{S}_{2}$, compared with plants in the treatment $\mathrm{S}_{6}$ (Table 1). However, the $\mathrm{Ci}$ in $\mathrm{S}_{2}$ was $85.43 \mu \mathrm{mol} \mathrm{m} \mathrm{m}^{-2} \mathrm{~s}^{-1}$ lower than in $\mathrm{S}_{5}$. On the other hand, there was a reduction of $61.51 \mu \mathrm{mol} \mathrm{m} \mathrm{m}^{-2} \mathrm{~s}^{-1}$ in $\mathrm{Ci}$ when $\mathrm{S}_{5}$ was compared with the other types of salt in the irrigation water $\left(\mathrm{S}_{2} ; \mathrm{S}_{3} ; \mathrm{S}_{4}\right.$ and $\left.\mathrm{S}_{6}\right)$. It should be pointed out that higher $\mathrm{Ci}\left(\mathrm{S}_{2} ; \mathrm{S}_{3} ; \mathrm{S}_{4}\right.$ and $\left.\mathrm{S}_{6}\right)$ means that the carbon entering the leaf mesophyll cells was not being metabolized by the photosynthetic apparatus. In addition, such increase in $\mathrm{Ci}$ is an indication that there was no restriction for $\mathrm{CO}_{2}$ absorption by the plant; however, when it reached the mesophyll cells, the process of fixation during the carboxylation phase was compromised (Habermann et al., 2003). The different types of water salinity also had significant influence on $A$ (Fig 2B), and plants under lowsalinity water $\left(\mathrm{S}_{1}\right)$ and receiving water containing $\mathrm{K}\left(\mathrm{S}_{5}\right)$ were statistically superior to the other treatments $\left(\mathrm{S}_{2}, \mathrm{~S}_{3}, \mathrm{~S}_{4}\right.$ and $\mathrm{S}_{6}$ ). According to the estimate of the mean for the contrasts (Table 1), the $\mathrm{CO}_{2}$ assimilation rate increased by $9.92 \mu \mathrm{mol} \mathrm{m} \mathrm{m}^{-2} \mathrm{~s}^{-1}$ in plants subjected to water of $0.6 \mathrm{dS} \mathrm{m}^{-1}$, in comparison to those receiving water of $4.5 \mathrm{dS} \mathrm{m}^{-1}\left(\mathrm{~S}_{2} ; \mathrm{S}_{3}\right.$; $\mathrm{S}_{4} ; \mathrm{S}_{5}$ and $\mathrm{S}_{6}$ ).

For the contrast $\mathrm{S}_{2}$ vs $\mathrm{S}_{6}$ (Table 3), when irrigation water containing $\mathrm{Na}$ was used $\left(\mathrm{S}_{2}\right)$, plants showed a reduction of $4.52 \mu \mathrm{mol} \mathrm{m} \mathrm{m}^{-2} \mathrm{~s}^{-1}$ in the $\mathrm{CO}_{2}$ assimilation rate, compared with $\mathrm{S}_{6}$. For $\mathrm{S}_{2}$ vs $\mathrm{S}_{5}$ (Table 1), plants irrigated with water containing $\mathrm{Na}\left(\mathrm{S}_{2}\right)$ showed a decrease of $13.69 \mu \mathrm{mol} \mathrm{m} \mathrm{m}^{-2} \mathrm{~s}^{-1}$ in $A$ compared with those in $\mathrm{S}_{5}$. On the other hand, when plants were irrigated with $\mathrm{S}_{5}(\mathrm{~K}), A$ increased by $11.41 \mu \mathrm{mol}$ $\mathrm{m}^{-2} \mathrm{~s}^{-1}$, compared with the other treatments under $\mathrm{ECw}=4.5$ $\mathrm{dS} \mathrm{m}{ }^{-1}\left(\mathrm{~S}_{2} ; \mathrm{S}_{3} ; \mathrm{S}_{4}\right.$ and $\left.\mathrm{S}_{6}\right)$. Based on the results above, it can be inferred that the reduction of the $\mathrm{CO}_{2}$ assimilation rate is a reflex of the decrease in transpiration and stomatal conductance, and the highest effect was due to the variation of water salinity (from 0.6 to $4.5 \mathrm{dS} \mathrm{m}^{-1}$ ). Likewise, Lima et al. (2014a) observed reduction in the $\mathrm{CO}_{2}$ assimilation rate of castor bean as a function of irrigation water salinity $(\mathrm{ECw}$ from 0.3 to $3.9 \mathrm{dS} \mathrm{m} \mathrm{m}^{-1}$ ). A significant difference was observed between the intrinsic WUE values of the studied treatments (Table 1) and, according to the means comparison test (Fig 3A), WUE was statistically higher in the treatment using low-salinity water $\left(\mathrm{S}_{1}\right)$ and water containing $\mathrm{K}\left(\mathrm{S}_{5}\right)$, in comparison to the other treatments $\left(\mathrm{S}_{2} ; \mathrm{S}_{3} ; \mathrm{S}_{4}\right.$ and $\left.\mathrm{S}_{6}\right)$. However, no significant differences were observed when plants under these treatments were compared. According to the contrasts (Table 1), WUE increased by $2.96\left(\mu \mathrm{mol} \mathrm{m} \mathrm{m}^{-2} \mathrm{~s}\right.$ $\left.{ }^{1}\right)\left(\mathrm{mol} \mathrm{H}_{2} \mathrm{O} \mathrm{m}^{-2} \mathrm{~s}^{-1}\right)^{-1}$ in plants subjected to $\mathrm{ECw}=0.6 \mathrm{dS} \mathrm{m}^{-1}$ 
Table 1. Summary of $\mathrm{F}$ test and estimated means of different contrasts $(\hat{\mathrm{y}})$ related to the stomatal conductance $(g s)$, transpiration $(E)$, internal $\mathrm{CO}_{2}$ concentration $(\mathrm{Ci}), \mathrm{CO}_{2}$ assimilation rate $(A)$, intrinsic water use efficiency (WUE) and instantaneous carboxylation efficiency (EICI) of castor bean cv. 'BRS Energia' irrigated with water of different types of salinity at 80 days after sowing.

\begin{tabular}{ccccccc}
\hline \multirow{2}{*}{ SV } & \multicolumn{7}{c}{$\mathrm{F}$ test } \\
\cline { 2 - 7 } Blocks & $g s$ & $E$ & $\mathrm{Ci}$ & $A$ & WUE & EICI \\
\cline { 2 - 7 } Types of Salinity & $\mathrm{ns}$ & $\mathrm{ns}$ & $\mathrm{ns}$ & $\mathrm{ns}$ & $\mathrm{ns}$ & $\mathrm{ns}$ \\
$\hat{\mathrm{y}}_{1}$ & $*$ & $*$ & $* *$ & $* *$ & $* *$ & $*$ \\
$\hat{\mathrm{y}}_{2}$ & $*$ & $*$ & $* *$ & $* *$ & $* *$ & $*$ \\
$\hat{\mathrm{y}}_{3}$ & $\mathrm{~ns}$ & $\mathrm{~ns}$ & $*$ & $\mathrm{~ns}$ & $*$ & $\mathrm{~ns}$ \\
$\hat{\mathrm{y}}_{4}$ & $\mathrm{~ns}$ & $*$ & $*$ & $*$ & $*$ & $\mathrm{~ns}$ \\
$\hat{\mathrm{y}}_{5}$ & $*$ & $*$ & $* *$ & $* *$ & $* *$ & $*$ \\
$\mathrm{CV}$ & $*$ & $*$ & $* *$ & $* *$ & $* *$ & $*$ \\
\hline & 14.41 & 14.94 & 6.60 & 19.13 & 14.69 & 18.71 \\
\hline$\hat{\mathrm{y}}_{1}$ & 0.09 & 0.53 & -72.71 & 9.92 & 2.96 & 0.05 \\
$\hat{\mathrm{y}}_{2}$ & $\mathrm{~ns}$ & $\mathrm{~ns}$ & 33.81 & $\mathrm{~ns}$ & -1.17 & $\mathrm{~ns}$ \\
$\hat{\mathrm{y}}_{3}$ & $\mathrm{~ns}$ & -0.54 & 30.18 & -4.52 & -1.35 & $\mathrm{~ns}$ \\
$\hat{\mathrm{y}}_{4}$ & -0.13 & -0.88 & 85.43 & -13.69 & -4.05 & -0.06 \\
$\hat{\mathrm{y}}_{5}$ & 0.10 & 0.62 & -61.51 & 11.41 & 3.26 & 0.05 \\
\hline
\end{tabular}

$\hat{\mathrm{y}}_{1}\left(\mathrm{~S}_{1}\right.$ vs $\left.\mathrm{S}_{2} ; \mathrm{S}_{3} ; \mathrm{S}_{4} ; \mathrm{S}_{5} ; \mathrm{S}_{6}\right) ; \hat{\mathrm{y}}_{2}\left(\mathrm{~S}_{2}\right.$ vs $\left.\mathrm{S}_{3}\right) ; \hat{\mathrm{y}}_{3}\left(\mathrm{~S}_{2}\right.$ vs $\left.\mathrm{S}_{6}\right) ; \hat{\mathrm{y}}_{4}\left(\mathrm{~S}_{2}\right.$ vs $\left.\mathrm{S}_{5}\right) ; \hat{\mathrm{y}}_{5}\left(\mathrm{~S}_{5}\right.$ vs $\left.\mathrm{S}_{2} ; \mathrm{S}_{3} ; \mathrm{S}_{4} ; \mathrm{S}_{6}\right) ;$

$\mathrm{S}_{1}=$ Control; $\mathrm{S}_{2}=\mathrm{Na}^{+} ; \mathrm{S}_{3}=\mathrm{Ca}^{2+} ; \mathrm{S}_{4}=\mathrm{Na}^{+}+\mathrm{Ca}^{2+} ; \mathrm{S}_{5}=\mathrm{K}^{+} ; \mathrm{S}_{6}=\mathrm{Na}^{+}+\mathrm{Ca}^{2+}+\mathrm{Mg}^{2+} ; \mathrm{SV}$ - Source of variation; DF - Degree of freedom; $\mathrm{CV}-$ Coefficient of variation; $(*)$ and $(* *)$ Significant at 0.05 and 0.01 probability; (ns) not significant.
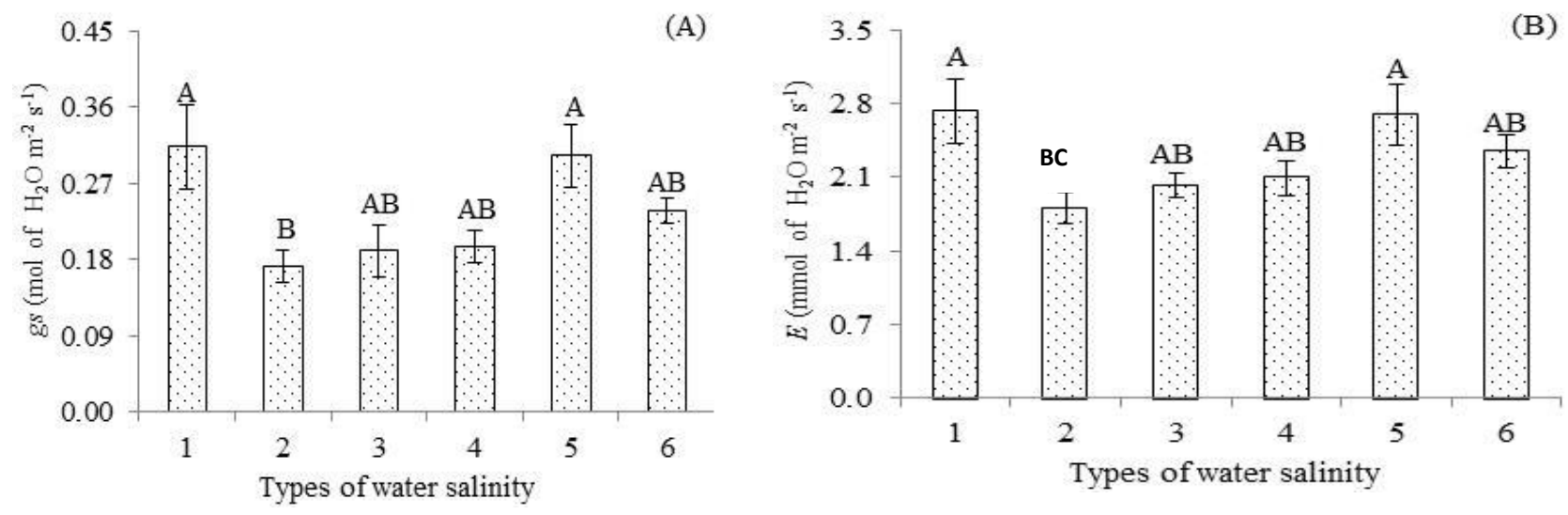

Fig 1. Stomatal conductance - $g s(\mathrm{~A})$ and transpiration - $E(\mathrm{~B})$ of castor bean cv. 'BRS Energia', depending on the types of irrigation water salinity at 80 days after sowing. $\mathrm{S}_{1}=\mathrm{Control} ; \mathrm{S}_{2}=\mathrm{Na}^{+} ; \mathrm{S}_{3}=\mathrm{Ca}^{2+} ; \mathrm{S}_{4}=\mathrm{Na}^{+}+\mathrm{Ca}^{2+} ; \mathrm{S}_{5}=\mathrm{K}^{+} ; \mathrm{S}_{6}=\mathrm{Na}^{+}+\mathrm{Ca}^{2+}+\mathrm{Mg}^{2+} ; \mathrm{Bars}^{2}$ represent the standard error of the mean $(n=4)$. Means followed by different letters differ significantly at 0.05 probabilty level.

compared with those under $\mathrm{ECW}=4.5 \mathrm{dS} \mathrm{m}^{-1}$. The intrinsic water use efficiency in $\mathrm{S}_{2}$ was $1.17\left(\mu \mathrm{mol} \mathrm{m}{ }^{-2} \mathrm{~s}^{-1}\right)\left(\mathrm{mol} \mathrm{H}_{2} \mathrm{O}\right.$ $\left.\mathrm{m}^{-2} \mathrm{~s}^{-1}\right)^{-1}$ lower than in $\mathrm{S}_{3}$. Plants receiving water containing $\mathrm{Na}\left(\mathrm{S}_{2}\right)$ showed a reduction of $1.35\left(\mu \mathrm{mol} \mathrm{m}^{-2} \mathrm{~s}^{-1}\right)\left(\mathrm{mol} \mathrm{H}_{2} \mathrm{O}\right.$ $\left.\mathrm{m}^{-2} \mathrm{~s}^{-1}\right)^{-1}$ in WUE compared with those irrigated using water containing $\mathrm{Na}+\mathrm{Ca}+\mathrm{Mg}\left(\mathrm{S}_{6}\right)$. Plants in the $\mathrm{S}_{2}$ treatment showed a reduction of $4.05\left(\mu \mathrm{mol} \mathrm{m} \mathrm{m}^{-2}\right)\left(\mathrm{mol} \mathrm{H}_{2} \mathrm{O} \mathrm{m}^{-2} \mathrm{~s}^{-1}\right)^{-1}$ in WUE, compared with those receiving water containing $\mathrm{K}$ $\left(\mathrm{S}_{5}\right)$. Plants in $\mathrm{S}_{5}$ showed an increment of $3.26\left(\mu \mathrm{mol} \mathrm{m} \mathrm{m}^{-2} \mathrm{~s}^{-1}\right)$ $\left(\mathrm{mol} \mathrm{H} \mathrm{O} \mathrm{m}^{-2} \mathrm{~s}^{-1}\right)^{-1}$ in WUE, in comparison to the treatments with other types of salt $\left(\mathrm{S}_{2} ; \mathrm{S}_{3} ; \mathrm{S}_{4}\right.$ and $\left.\mathrm{S}_{6}\right)$. The decrease in WUE observed in the treatments $S_{2}, S_{3}, S_{4}$ and $S_{6}$ (Fig 3A) is due to the decrease in stomatal conductance (Fig 1A) and transpiration (Fig 1B), because when $g s$ is limited in order to reduce water loss $(E)$, the $\mathrm{CO}_{2}$ inflow to the cell and the $\mathrm{CO}_{2}$ assimilation rate also decrease. It should be noted that WUE relates the amount of carbon fixed by the plant per unit of water lost in this process (Taiz and Zeiger, 2013). Thus, it is important to absorb as much $\mathrm{CO}_{2}$ as possible with the minimum water loss, a fact observed in plants irrigated with low-salinity water $\left(S_{1}\right)$ and water containing $K\left(S_{5}\right)$. As to the instantaneous carboxylation efficiency (EICI) (Fig 3B), plants irrigated with low-salinity water $\left(S_{1}\right)$ and water containing $\mathrm{K}\left(\mathrm{S}_{5}\right)$ were statistically superior to plants under the other types of salinity $\left(\mathrm{S}_{2} ; \mathrm{S}_{3} ; \mathrm{S}_{4}\right.$ and $\left.\mathrm{S}_{6}\right)$. However, these treatments did not differ significantly. According to the estimate of the mean (Table 1), EICI increased by 0.05 $\left[\left(\mu \mathrm{mol} \mathrm{m} \mathrm{s}^{-1}\right)\left(\mu \mathrm{mol} \mathrm{mol}^{-1}\right]^{-1}\right.$ in plants under low-salinity water $\left(0.6 \mathrm{dS} \mathrm{m}^{-1}\right)$, compared with those under $\mathrm{ECw}$ of 4.5 $\mathrm{dS} \mathrm{m}{ }^{-1}\left(\mathrm{~S}_{2} ; \mathrm{S}_{3} ; \mathrm{S}_{4} ; \mathrm{S}_{5} ; \mathrm{S}_{6}\right)$. For the contrasts $\mathrm{S}_{2}$ vs $\mathrm{S}_{3}$ and $\mathrm{S}_{2}$ vs $S_{6}$, there was no significant effect on EICI. On the other hand, significant effect was observed for $\mathbf{S}_{2} v s \mathbf{S}_{5}$ and $\mathbf{S}_{5} v s$ $\mathrm{S}_{2} ; \mathrm{S}_{3} ; \mathrm{S}_{4}$ and $\mathrm{S}_{6}$. EICI decreased by $0.06\left[\left(\mu \mathrm{mol} \mathrm{m} \mathrm{m}^{-2} \mathrm{~s}^{-1}\right)\right.$ $\left(\mu \mathrm{mol} \mathrm{mol}{ }^{-1}\right]^{-1}$ in plants in $S_{2}$, compared with those receiving water containing $\mathrm{K}\left(\mathrm{S}_{5}\right)$ (Table 1). Plants subjected to the treatment $\mathrm{S}_{5}$ tended to increase EICI (Table 1), with mean 
Table 2. Summary of $F$ test and estimated means of different contrasts ( $\hat{y})$ related to the plant height $(\mathrm{PH})$, stem diameter (SD), number of leaves (NL) and leaf area (LA), oil content (OC) and oil yield (OY) of castor bean cv. 'BRS Energia' irrigated with water of different types of salinity at 80 days after sowing.

\begin{tabular}{|c|c|c|c|c|c|c|}
\hline \multirow{2}{*}{ SV } & \multicolumn{6}{|c|}{ F test } \\
\hline & $\mathrm{PH}$ & SD & $\mathrm{NL}$ & LA & $\mathrm{OC}$ & $\mathrm{OY}$ \\
\hline Blocks & ns & ns & ns & ns & ns & ns \\
\hline Types of Salinity & $* *$ & $* *$ & $* *$ & $* *$ & $* *$ & $* *$ \\
\hline$\hat{\mathrm{y}}_{1}$ & $* *$ & $* *$ & $* *$ & * & $*$ & $* *$ \\
\hline$\hat{\mathrm{y}}_{2}$ & ns & ns & ns & ns & ns & ns \\
\hline$\hat{\mathrm{y}}_{3}$ & ns & ns & ns & ns & ns & ns \\
\hline$\hat{\mathrm{y}}_{4}$ & $*$ & $*$ & $*$ & $*$ & $* *$ & $* *$ \\
\hline$\hat{\mathrm{y}}_{5}$ & $*$ & $*$ & $* *$ & $*$ & $*$ & $*$ \\
\hline \multirow{2}{*}{$\mathrm{CV}$} & 6.76 & 9.69 & 18.46 & 15.46 & 7.73 & 14.01 \\
\hline & \multicolumn{6}{|c|}{ Mean estimate } \\
\hline$\hat{\mathrm{y}}_{1}$ & 25.69 & 7.75 & 18.77 & 11125.86 & 9.05 & 49.68 \\
\hline$\hat{\mathrm{y}}_{2}$ & ns & ns & ns & ns & ns & ns \\
\hline$\hat{\mathrm{y}}_{3}$ & ns & ns & ns & ns & ns & ns \\
\hline$\hat{\mathrm{y}}_{4}$ & -9.12 & -3.55 & -10.50 & -1757.00 & 12.61 & 11.06 \\
\hline$\hat{\mathrm{y}}_{5}$ & 7.41 & 3.15 & 9.87 & 1457.39 & 5.25 & -3.39 \\
\hline
\end{tabular}

$\hat{\mathrm{y}}_{1}\left(\mathrm{~S}_{1}\right.$ vs $\left.\mathrm{S}_{2} ; \mathrm{S}_{3} ; \mathrm{S}_{4} ; \mathrm{S}_{5} ; \mathrm{S}_{6}\right) ; \hat{\mathrm{y}}_{2}\left(\mathrm{~S}_{2}\right.$ vs $\left.\mathrm{S}_{3}\right) ; \hat{\mathrm{y}}_{3}\left(\mathrm{~S}_{2}\right.$ vs $\left.\mathrm{S}_{6}\right) ; \hat{\mathrm{y}}_{4}\left(\mathrm{~S}_{2}\right.$ vs $\left.\mathrm{S}_{5}\right) ; \hat{\mathrm{y}}_{5}\left(\mathrm{~S}_{5}\right.$ vs $\left.\mathrm{S}_{2} ; \mathrm{S}_{3} ; \mathrm{S}_{4} ; \mathrm{S}_{6}\right)$

$\mathrm{S}_{1}=$ Control; $\mathrm{S}_{2}=\mathrm{Na}^{+} ; \mathrm{S}_{3}=\mathrm{Ca}^{2+} ; \mathrm{S}_{4}=\mathrm{Na}^{+}+\mathrm{Ca}^{2+} ; \mathrm{S}_{5}=\mathrm{K}^{+} ; \mathrm{S}_{6}=\mathrm{Na}^{+}+\mathrm{Ca}^{2+}+\mathrm{Mg}^{2+} ; \mathrm{SV}-$ Source of variation; DF- Degree of freedom; CV Coefficient of variation; $(*)$ and $(* *)$ Significant at 0.05 and 0.01 probability; (ns) not significant.
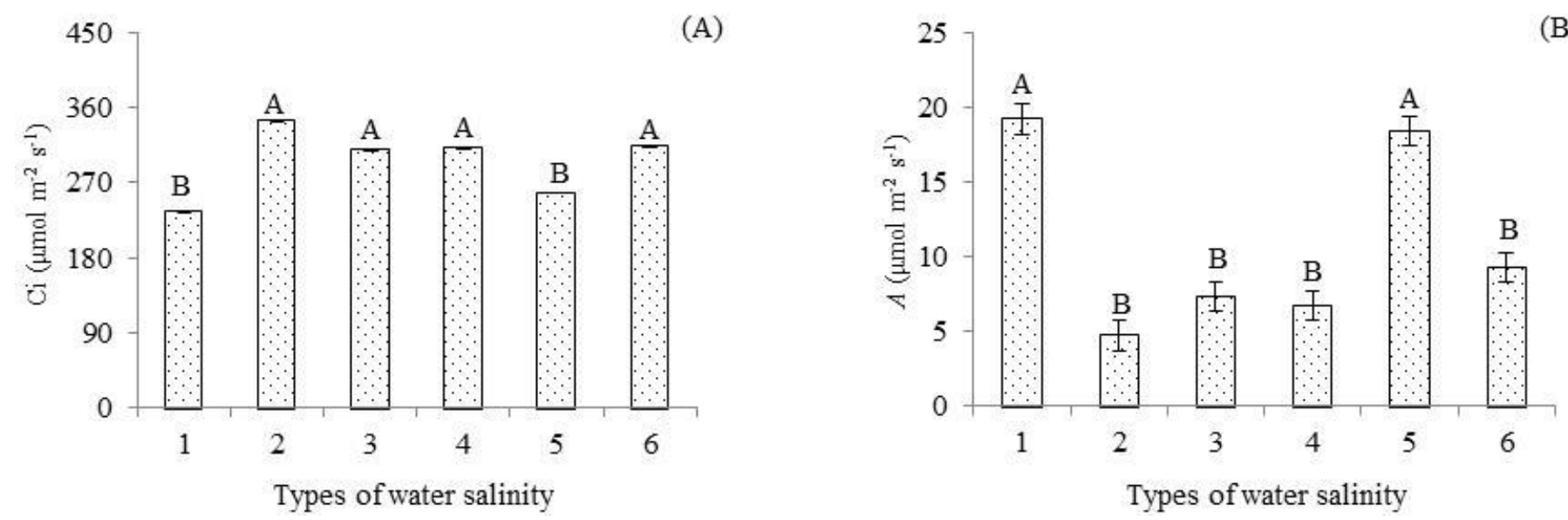

Fig 2. Internal $\mathrm{CO}_{2}$ concentration - $\mathrm{Ci}(\mathrm{A})$ and $\mathrm{CO}_{2}$ assimilation rate - $A(\mathrm{~B})$ of castor bean cv. 'BRS Energia', depending on the types of irrigation water salinity at 80 days after sowing. $\mathrm{S}_{1}=\mathrm{Control} ; \mathrm{S}_{2}=\mathrm{Na}^{+} ; \mathrm{S}_{3}=\mathrm{Ca}^{2+} ; \mathrm{S}_{4}=\mathrm{Na}^{+}+\mathrm{Ca}^{2+} ; \mathrm{S}_{5}=\mathrm{K}^{+} ; \mathrm{S}_{6}=$ $\mathrm{Na}^{+}+\mathrm{Ca}^{2+}+\mathrm{Mg}^{2+}$; Bars represent the standard error of the mean $(\mathrm{n}=4)$. Means followed by different letters differ significantly at 0.05 probabilty level.

value of $\left.0.05\left[\left(\mu \mathrm{mol} \mathrm{m} \mathrm{m}^{-1}\right)(\mu \mathrm{mol} \mathrm{mol})^{-1}\right)\right]^{-1}$, higher than in the other treatments $\left(\mathrm{S}_{2} ; \mathrm{S}_{3} ; \mathrm{S}_{4}\right.$ and $\left.\mathrm{S}_{6}\right)$. The results suggest that this higher decrease in EICI in the treatments $S_{2}, S_{3}, S_{4}$ and $\mathrm{S}_{6}$ is a reflex of the low $\mathrm{CO}_{2}$ assimilation rates (Fig 2B), in relation to the $\mathrm{CO}_{2}$ content in the substomatal chamber (Fig 2A). Machado et al. (2005) reported that the instantaneous carboxylation efficiency is closely related to the $\mathrm{CO}_{2}$ assimilation rate and the intracellular $\mathrm{CO}_{2}$ concentration.

\section{Effect of irrigation water salinity and cationic nature on growth and oil yield}

Based on the summary of the F test (Table 2), there was significant effect $(p<0.01)$ of the different types of water salinity on $\mathrm{PH}, \mathrm{SD}, \mathrm{NL}, \mathrm{LA}, \mathrm{OC}$ and $\mathrm{OY}$ of castor bean. Lima et al. (2014b), studying the influence of irrigation with saline water simulated with $\mathrm{NaCl}$ ( $\mathrm{ECw}$ from 0.3 to 3.9 $\mathrm{dSm}^{-1}$, also observed significant effect on plant height, stem diameter, number of leaves and leaf area at 60 DAS. According to the means comparison test for PH (Fig 4A), plants irrigated with low-salinity water $\left(S_{1}\right)$ statistically differed $(\mathrm{p}<0.01)$ from those irrigated with high-salinity water and different ionic compositions $\left(\mathrm{S}_{2} ; \mathrm{S}_{3} ; \mathrm{S}_{4} ; \mathrm{S}_{5}\right.$ and $\left.\mathrm{S}_{6}\right)$. The treatment $\mathrm{S}_{5}$ differed significantly regarding $\mathrm{PH}$ from treatments with $\mathrm{Na}\left(\mathrm{S}_{2}\right)$ and $\mathrm{Ca}\left(\mathrm{S}_{3}\right)$, which did not differ significantly from $\mathrm{S}_{4}$ and $\mathrm{S}_{6}$. Based on the contrasts of means (Table 2$)$, PH varied significantly $(\mathrm{p}<0.01)$ and increased by $25.69 \mathrm{~cm}$ in the treatment with $\mathrm{ECw}$ of $0.6 \mathrm{dS} \mathrm{m} \mathrm{m}^{-1}\left(\mathrm{~S}_{1}\right)$, compared with those under $4.5 \mathrm{dS} \mathrm{m}{ }^{-1}\left(\mathrm{~S}_{2} ; \mathrm{S}_{3} ; \mathrm{S}_{4} ; \mathrm{S}_{5}\right.$ and $\left.\mathrm{S}_{6}\right)$. These results agree with Lima et al. (2014b), who observed that the increase in irrigation water salinity ( $\mathrm{ECw}$ from 0.3 to $3.9 \mathrm{dS} \mathrm{m}^{-1}$ ) reduced $\mathrm{PH}$ of the castor bean cultivar 'BRS Energia' at 30,60 and 120 DAS. This tendency for a decrease in $\mathrm{PH}$ under saline-stress conditions can be attributed to the fact that, in order to adjust osmotically, plants spend a certain amount of energy in the accumulation of sugars, organic acids and ions in the vacuole, which could be used for growth (Santos et al., 2012). As to the treatments $\mathrm{S}_{2} v s \mathrm{~S}_{3}$ and $\mathrm{S}_{2} v s \mathrm{~S}_{6}$, there was no significant effect on PH. Therefore, the results suggest that $\mathrm{Na}, \mathrm{Ca}$ and $\mathrm{Mg}$ acted similarly on plant growth. On the other hand, there was significant effect for $\mathrm{S}_{2} v s \mathrm{~S}_{5}$ and $\mathrm{S}_{5} v s\left(\mathrm{~S}_{2} ; \mathrm{S}_{3} ; \mathrm{S}_{4}\right.$ and $\left.\mathrm{S}_{6}\right)$ and, according to the estimate of the mean (Table 2), plants 
Table 3. Chemical characteristics of the water used in the experiment.

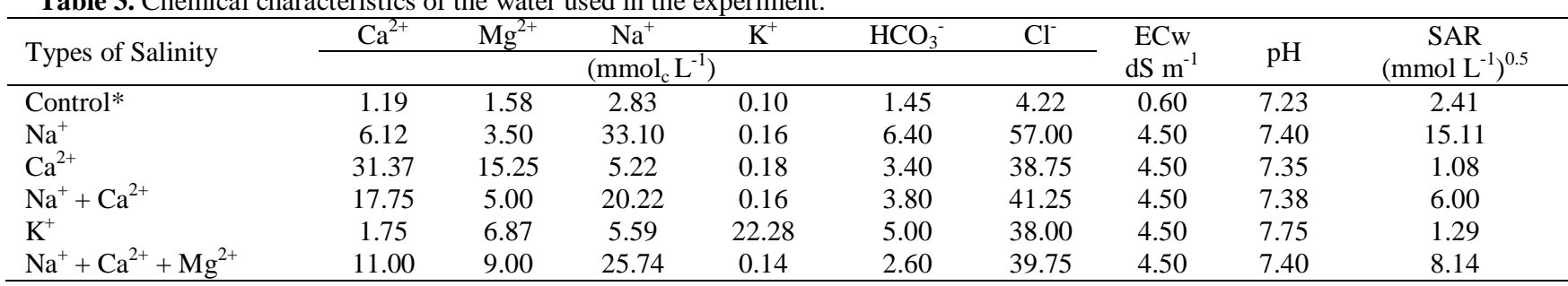

*Obtained by dilution of the water of supply system (Campina Grande, Paraiba) with rain water; ECw - electrical conductivity of water; SAR - sodium adsorption ratio; $\mathrm{CO}_{3}^{2-}=$ absent.
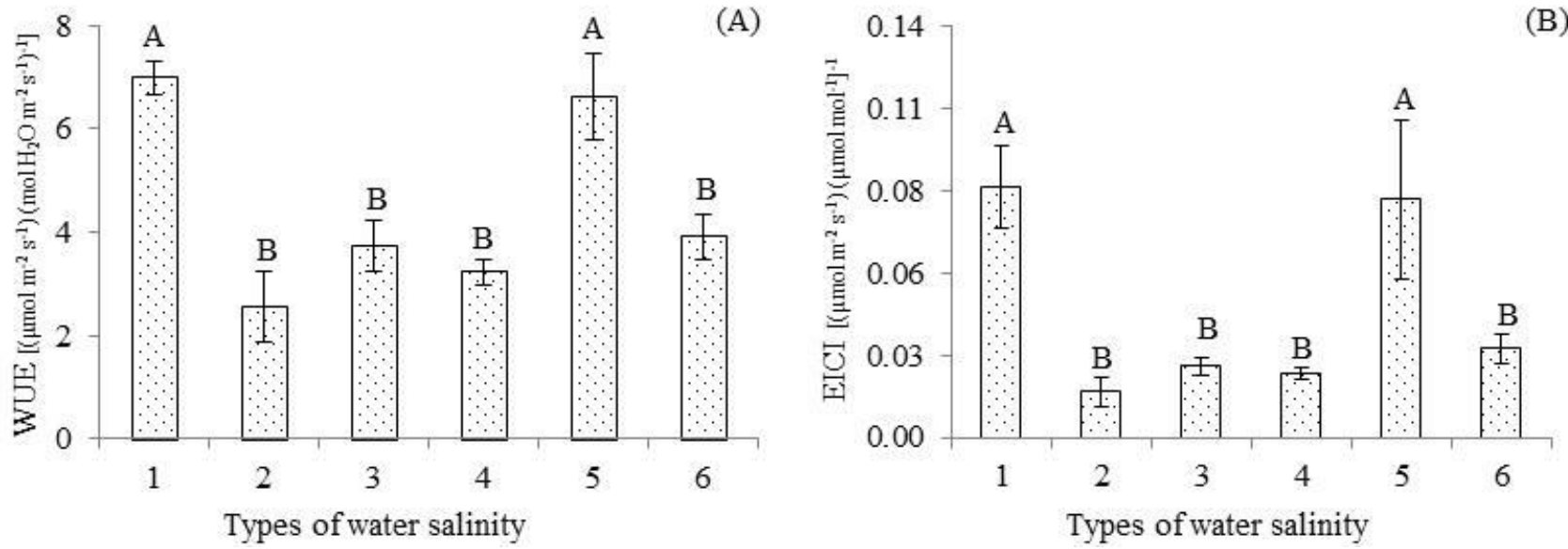

Fig 3. Intrinsic water use efficiency - WUE (A) and instantaneous carboxylation efficiency EICI (B) of castor bean cv. 'BRS Energia', depending on the types of irrigation water salinity at 80 days after sowing. $\mathrm{S}_{1}=$ Control; $\mathrm{S}_{2}=\mathrm{Na}^{+} ; \mathrm{S}_{3}=\mathrm{Ca}^{2+} ; \mathrm{S}_{4}=\mathrm{Na}^{+}+\mathrm{Ca}^{2+}$; $\mathrm{S}_{5}=\mathrm{K}^{+} ; \mathrm{S}_{6}=\mathrm{Na}^{+}+\mathrm{Ca}^{2+}+\mathrm{Mg}^{2+}$; Bars represent the standard error of the mean $(\mathrm{n}=4)$. Means followed by different letters differ significantly at 0.05 probabilty level.

Table 4. Chemical and physical characteristics of the soil used in the experiment before application of treatments.

\begin{tabular}{|c|c|c|c|c|c|c|c|c|c|}
\hline \multicolumn{10}{|c|}{ Chemical characteristics } \\
\hline $\mathrm{pH}_{\mathrm{ps}}$ & M.O & $\mathrm{P}$ & $\mathrm{K}^{+}$ & $\mathrm{Na}^{+}$ & $\mathrm{Ca}^{2+}$ & $\mathrm{Mg}^{2+}$ & $\mathrm{Al}^{3+}$ & $\mathrm{H}^{+}$ & \multirow{2}{*}{ 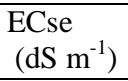 } \\
\hline & dag $\mathrm{kg}^{-1}$ & $\left(\mathrm{mg} \mathrm{kg}^{-1}\right)$ & \multicolumn{6}{|c|}{ 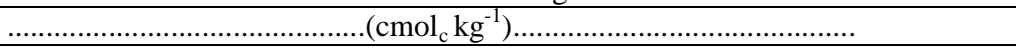 } & \\
\hline 5.10 & 0.34 & 20.09 & 0.07 & 0.05 & 0.40 & 1.30 & 0.04 & 1.74 & 0.16 \\
\hline \multicolumn{10}{|c|}{ Physical characteristics } \\
\hline \multicolumn{3}{|c|}{ Size fraction $\left(\mathrm{g} \mathrm{kg}^{-1}\right)$} & \multirow{2}{*}{$\begin{array}{l}\text { Textural } \\
\text { class }\end{array}$} & \multicolumn{2}{|c|}{ Water content $(\mathrm{kPa})$} & \multirow[t]{2}{*}{ AW } & \multirow{2}{*}{$\begin{array}{l}\text { Total } \\
\text { porosity } \\
\mathrm{m}^{3} \mathrm{~m}^{-3}\end{array}$} & \multirow{2}{*}{$\begin{array}{l}\mathrm{BD} \\
\left(\mathrm{kg} \mathrm{dm}^{-3}\right)\end{array}$} & \multirow{2}{*}{$\begin{array}{l}\text { DP } \\
\left(\mathrm{kg} \mathrm{dm}^{-3}\right)\end{array}$} \\
\hline Sand & Silt & Clay & & $\begin{array}{l}33.42 \\
\ldots \ldots \ldots \ldots \ldots\end{array}$ & $\begin{array}{l}1519.5 \\
\text { dag kg }\end{array}$ & & & & \\
\hline 856.10 & 110.70 & 33.20 & SL & 6.72 & 1.62 & 5.10 & 0.49 & 1.54 & 2.72 \\
\hline
\end{tabular}

$\mathrm{pH}_{\mathrm{PS}^{-}} \mathrm{pH}$ of saturated paste; O.M - organic matter: determined by wet digestion Walkley-Black method; $\mathrm{Ca}^{2+}$ and $\mathrm{Mg}^{2+}$ extracted with $\mathrm{KCl} 1 \mathrm{~mol} \mathrm{~L}^{-1}$ at $\mathrm{pH} 7.0 ; \mathrm{Na}^{+}$and $\mathrm{K}^{+}$ extracted with $\mathrm{NH}_{4} \mathrm{OAc} 1 \mathrm{~mol} \mathrm{~L}-1$ at $\mathrm{pH}$ 7.0; $\mathrm{SL}$-sandy loam; AW -available water; $\mathrm{BD}$ - Bulk density; DP-density particles; ECse-electrical conductivity of the saturation extract.
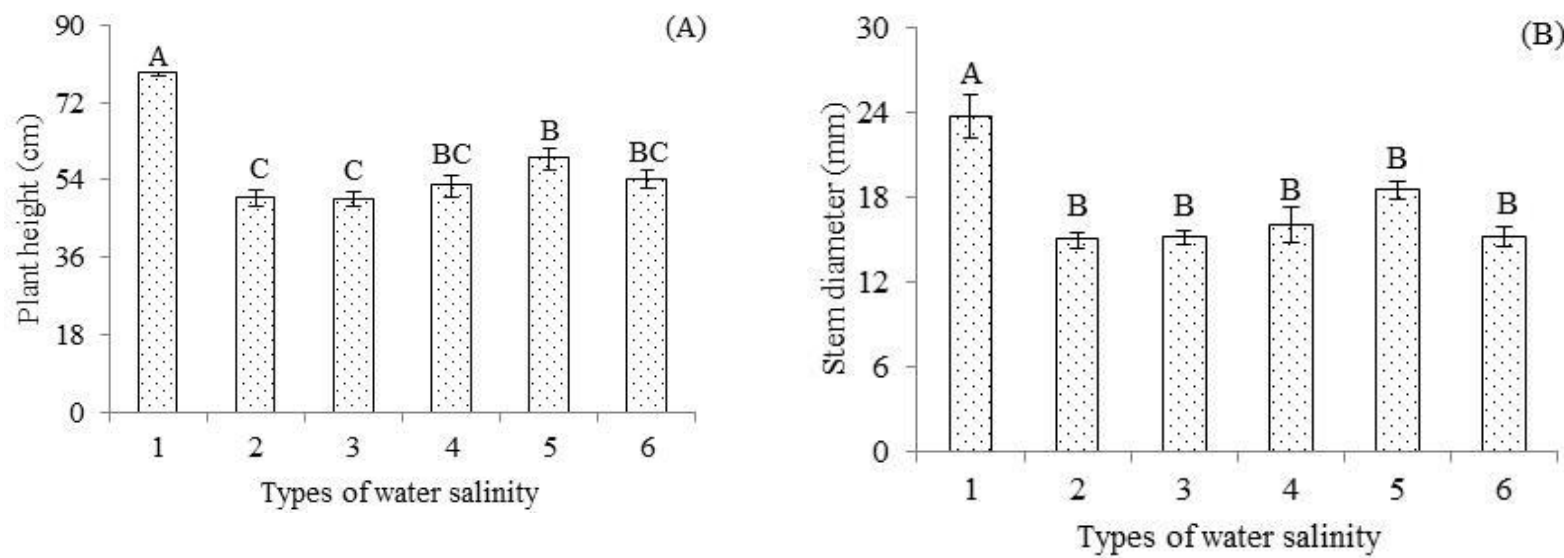

Fig 4. Plant height $(\mathrm{A})$ and stem diameter $(\mathrm{B})$ of castor bean cv. 'BRS Energia', depending on the types of irrigation water salinity at 80 days after sowing. $\mathrm{S}_{1}=$ Control; $\mathrm{S}_{2}=\mathrm{Na}^{+} ; \mathrm{S}_{3}=\mathrm{Ca}^{2+} ; \mathrm{S}_{4}=\mathrm{Na}^{+}+\mathrm{Ca}^{2+} ; \mathrm{S}_{5}=\mathrm{K}^{+} ; \mathrm{S}_{6}=\mathrm{Na}^{+}+\mathrm{Ca}^{2+}+\mathrm{Mg}^{2+} ;$ Bars represent the standard error of the mean $(n=4)$. Means followed by different letters differ significantly at 0.05 probabilty level. 

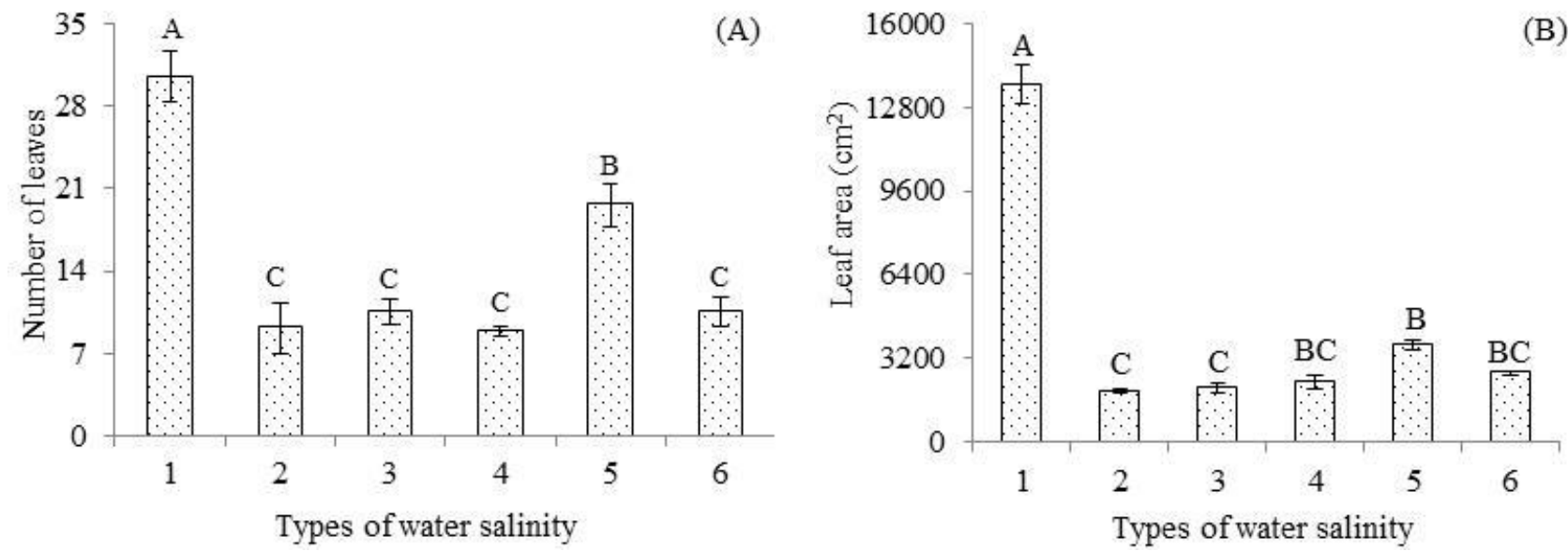

Fig 5. Number of leaves (NL) and leaf area (LA) of castor bean cv. 'BRS Energia', depending on the types of irrigation water salinity at 80 days after sowing. $\mathrm{S}_{1}=\mathrm{C}$ Control; $\mathrm{S}_{2}=\mathrm{Na}^{+} ; \mathrm{S}_{3}=\mathrm{Ca}^{2+} ; \mathrm{S}_{4}=\mathrm{Na}^{+}+\mathrm{Ca}^{2+} ; \mathrm{S}_{5}=\mathrm{K}^{+} ; \mathrm{S}_{6}=\mathrm{Na}^{+}+\mathrm{Ca}^{2+}+\mathrm{Mg}^{2+}$; Bars represent the standard error of the mean $(n=4)$. Means followed by different letters differ significantly at 0.05 probabilty level.
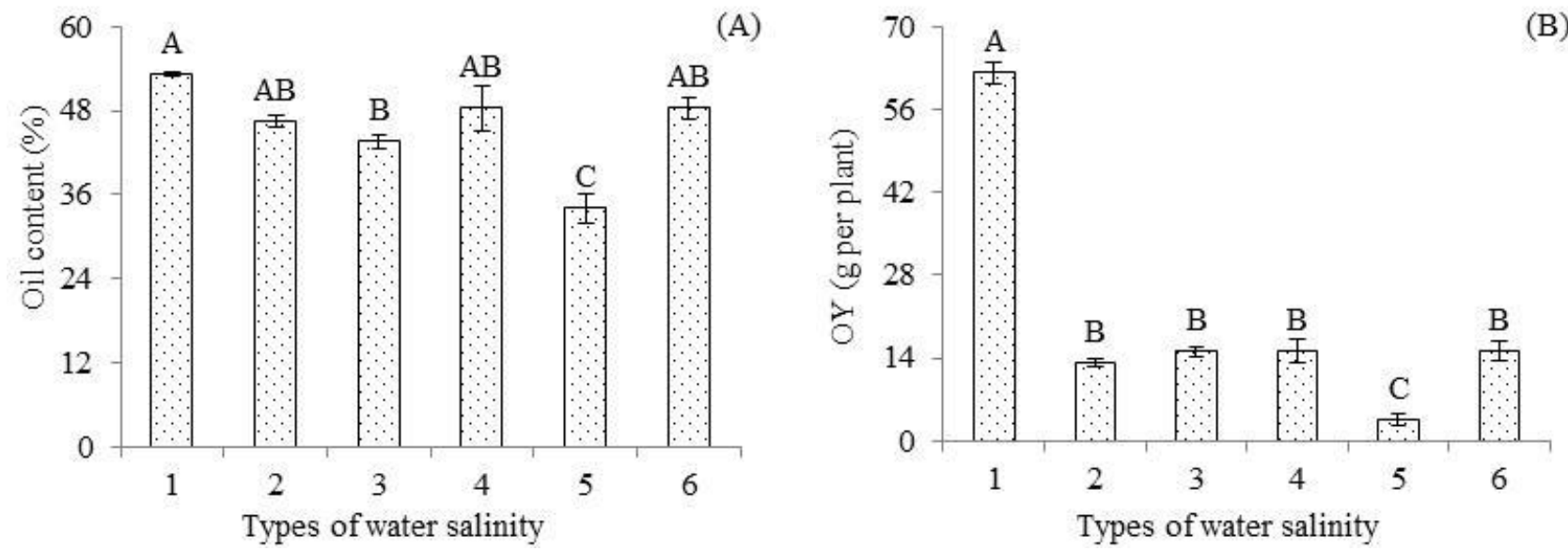

Fig 6. Oil content (A) and oil yield - OY (B) of castor bean cv. 'BRS Energia', depending on the types of irrigation water salinity at 100 days after sowing. $\mathrm{S}_{1}=$ Control; $\mathrm{S}_{2}=\mathrm{Na}^{+} ; \mathrm{S}_{3}=\mathrm{Ca}^{2+} ; \mathrm{S}_{4}=\mathrm{Na}^{+}+\mathrm{Ca}^{2+} ; \mathrm{S}_{5}=\mathrm{K}^{+} ; \mathrm{S}_{6}=\mathrm{Na}^{+}+\mathrm{Ca}^{2+}+\mathrm{Mg}^{2+}$; Bars represent the standard error of the mean $(n=4)$. Means followed by different letters differ significantly at 0.05 probabilty level.

irrigated using water containing $\mathrm{Na}\left(\mathrm{S}_{2}\right)$ showed $\mathrm{PH} 9.12 \mathrm{~cm}$ lower than those subjected to water containing $\mathrm{K}\left(\mathrm{S}_{5}\right)$, while plants in the treatment $\mathrm{S}_{5}$ tended to have higher $\mathrm{PH}$, with mean value of $7.41 \mathrm{~cm}$, compared with plants in the other treatments with $\mathrm{ECw}=4.5 \mathrm{dS} \mathrm{m}^{-1}\left(\mathrm{~S}_{2} ; \mathrm{S}_{3} ; \mathrm{S}_{4}\right.$ and $\left.\mathrm{S}_{6}\right)$. In spite of that, the highest $\mathrm{PH}$ observed for the treatment with water containing $\mathrm{K}\left(\mathrm{S}_{5}\right)$ is justified by the importance of this nutrient in plant metabolism, since it acts in the regulation of the osmotic potential of the cell, the balance of negative charges of the organic acids inside the cells and the balance of anions absorbed by the roots (Bernardi et al., 2010). According to the comparison of means for stem diameter (Fig 4B), as observed for PH (Fig 4A), there was a significant difference $(\mathrm{p}<0.05)$ between the control treatment $\left(\mathrm{S}_{1}\right)$ and the others $\left(\mathrm{S}_{2} ; \mathrm{S}_{3} ; \mathrm{S}_{4} ; \mathrm{S}_{5}\right.$ and $\left.\mathrm{S}_{6}\right)$, which did not differ ( $>>0.05$ ) statistically. Like PH (Table 2), significant effects were observed for SD when plants subjected to water of 0.6 $\mathrm{dS} \mathrm{m}{ }^{-1}\left(\mathrm{~S}_{1}\right)$ were compared with those under $4.5 \mathrm{dS} \mathrm{m}^{-1}\left(\mathrm{~S}_{2}\right.$; $\mathrm{S}_{3} ; \mathrm{S}_{4} ; \mathrm{S}_{5}$ and $\mathrm{S}_{6}$ ); $\mathrm{SD}$ was $7.75 \mathrm{~mm}$ higher in $\mathrm{S}_{1}$ compared with the others. Alves et al. (2012), studying the influence of irrigation water of $\mathrm{ECw}$ from 0.6 to $4.6 \mathrm{dS} \mathrm{m}^{-1}$ on the growth of the castor bean cultivar 'BRS Energia', observed a reduction of $3.32 \mathrm{~mm}$ in SD at 40 DAS. According to Table 2 , plants in the $S_{2}$ treatment were not significantly different ( $p>0.05$ ) from those in $S_{3}$ and $S_{6}$. Thus, it can be inferred that irrigation with different types of salt $\left(\mathrm{Na}^{+}, \mathrm{Ca}^{+2}, \mathrm{Mg}^{+2}\right)$ caused similar effects on $\mathrm{SD}$, but plants in $\mathrm{S}_{2}$ were significantly different $(\mathrm{p}<0.05)$ from those in $\mathrm{S}_{5}$, with $\mathrm{SD}$ value $3.55 \mathrm{~mm}$ lower. $\mathrm{SD}$ increased by $3.15 \mathrm{~mm}$ in the comparison of $\mathrm{S}_{5}$ vs $\mathrm{S}_{2}, \mathrm{~S}_{3}, \mathrm{~S} 4$ and $\mathrm{S}_{6}$. Based on the means comparison test for the number of leaves (Fig 5A), there was significant $(\mathrm{p}<0.05)$ difference between the studied salts and, as expected, the treatment $S_{1}$ was superior to the others $\left(\mathrm{S}_{2} ; \mathrm{S}_{3} ; \mathrm{S}_{4} ; \mathrm{S}_{5}\right.$ and $\left.\mathrm{S}_{6}\right)$. On the other hand, when the data were compared as a function of the types of salt in the irrigation water, the use of water containing $\mathrm{K}$ had significant and positive influence on NL and differed from $S_{2}, S_{3}, S_{4}$ and $S_{6}$. According to the estimate of the mean for the number of leaves (Table 2), plants receiving water of $0.6 \mathrm{dS} \mathrm{m}^{-1}\left(\mathrm{~S}_{1}\right)$ showed higher NL, exceeding in 18.77 the mean observed for plants under $4.5 \mathrm{dS} \mathrm{m}^{-1}\left(\mathrm{~S}_{2} ; \mathrm{S}_{3} ; \mathrm{S}_{4} ; \mathrm{S}_{5}\right.$ and $\left.\mathrm{S}_{6}\right)$. However, in the comparison of the treatments $\mathrm{S}_{2} v s \mathrm{~S}_{3}$ and $\mathrm{S}_{2} v s \mathrm{~S}_{6}$ (Table $2)$, there was no significant $(\mathrm{p}>0.05)$ influence on NL. On the other hand, NL was statistically lower when water 
containing $\mathrm{Na}\left(\mathrm{S}_{2}\right)$ was used in the irrigation, with a decrease of 10.50 leaves compared with the plants in $S_{5}$. Plants subjected to irrigation using water containing $\mathrm{K}\left(\mathrm{S}_{5}\right)$ showed an increment of 9.87 in NL compared with the other treatments under $\mathrm{ECw}=4.5 \mathrm{dS} \mathrm{m}^{-1}\left(\mathrm{~S}_{2}, \mathrm{~S}_{3}, \mathrm{~S}_{4}, \mathrm{~S}_{6}\right)($ Fig 5A). Thus, under saline stress conditions, morphological changes in the plants are common, which lead to the reduction of the transpiring surface as an alternative to maintain adequate water absorption, and the reduction in NL is among these adaptations (Oliveira et al., 2010), a fact also observed by Alves et al. (2012) and Lima et al. (2014a).

According to the comparison of means for leaf area (Fig $5 B)$, plants irrigated with low-salinity water $\left(S_{1}\right)$ showed the highest LA compared with the other treatments, as NL and the other analysed variables. Also, the LA of plants in the treatment $\mathrm{S}_{5}$ was significantly different only from those in $\mathrm{S}_{2}$ and $S_{3}$. In addition, the value obtained for LA in the treatments $\mathrm{S}_{4}, \mathrm{~S}_{5}$ and $\mathrm{S}_{6}$ did not differ. The estimate of the mean for LA (Table 2) shows an expressive increase in LA of plants under low-salinity water $\left(0.6 \mathrm{dS} \mathrm{m}^{-1}\right)$, exceeding the mean value in $11125.86 \mathrm{~cm}^{2}$, compared with those irrigated with water of $4.5 \mathrm{dS} \mathrm{m}^{-1}$. In addition, no significant influence on LA was observed when plants irrigated with water containing $\mathrm{Na}\left(\mathrm{S}_{2}\right)$ were compared with those receiving water containing $\mathrm{Ca}\left(\mathrm{S}_{3}\right)$ and $\mathrm{Na}+\mathrm{Ca}+\mathrm{Mg}\left(\mathrm{S}_{6}\right)$.

Still according to Table 2, LA was significantly affected in the plants in $S_{2}$, with a decrease of $1757.00 \mathrm{~cm}^{2}$ when compared with plants in $S_{5}$. However, in the comparison of the treatment $\mathrm{S}_{5} v s$ the others $\left(\mathrm{S}_{2}, \mathrm{~S}_{3}, \mathrm{~S}_{4}, \mathrm{~S}_{6}\right)$, LA increased by $1457.39 \mathrm{~cm}^{2}$, i.e., a reduction lower than that previously observed for the treatments $\mathrm{S}_{2} v s \mathrm{~S}_{5}$. Thus, the decreases in LA, especially in plants irrigated with water containing $\mathrm{Na}$ are reflections of the high accumulation of the ions $\mathrm{Na}^{+}$and $\mathrm{Cl}$ - in the soil solution, at levels that alter cell ionic balance. Also, the reductions in the number of leaves (Fig 5A) and leaf area (Fig 5B) in this study are an example of probable adaptations of plants cultivated under saline stress conditions. According to the means comparison test for oil content (Fig $6 \mathrm{~A}$ ), plants in $\mathrm{S}_{1}$ did not differ ( $\mathrm{p}>0.05$ ) from those receiving water containing $\mathrm{Na}\left(\mathrm{S}_{2}\right), \mathrm{Na}+\mathrm{Ca}\left(\mathrm{S}_{4}\right)$ and $\mathrm{Na}+\mathrm{Ca}+\mathrm{Mg}\left(\mathrm{S}_{6}\right)$. However, significant difference for OC was observed between the treatment using water with $\mathrm{K}\left(\mathrm{S}_{5}\right)$ and the others $\left(\mathrm{S}_{1}, \mathrm{~S}_{2}, \mathrm{~S}_{3}, \mathrm{~S}_{4}\right.$ and $\left.\mathrm{S}_{6}\right)$. The contrasts of means for OC (Table 2) showed no significant difference $(\mathrm{p}>0.05)$ for $\mathrm{S}_{2} v s \mathrm{~S}_{3}$ and $\mathrm{S}_{2}$ vs $\mathrm{S}_{6}$. Based on the estimate of the mean (Table 2), plants irrigated with low-salinity water $\left(0.6 \mathrm{dS} \mathrm{m}^{-1}\right)$ showed an increment of $9.05 \%$ in OC, when compared with those under ECw of $4.5 \mathrm{dS} \mathrm{m}^{-1}\left(\mathrm{~S}_{2} ; \mathrm{S}_{3} ; \mathrm{S}_{4} ; \mathrm{S}_{5}\right.$ and $\left.\mathrm{S}_{6}\right)$. On the other hand, when this variable was analyzed between plants receiving water with $\mathrm{Na}\left(\mathrm{S}_{2}\right)$ and $\mathrm{K}\left(\mathrm{S}_{5}\right)$, OC increased by $12.61 \%$. The oil content was $5.25 \%$ lower in $S_{5}$ compared with the other treatments with $\mathrm{ECw}=4.5 \mathrm{dS} \mathrm{m}{ }^{-1}\left(\mathrm{~S}_{2} ; \mathrm{S}_{3} ; \mathrm{S}_{4}\right.$ and $\mathrm{S}_{6}$ ).

As for oil yield (Fig 6B), plants in the control treatment $\left(\mathrm{S}_{1}\right)$ showed OY significantly higher compared with plants under other types of water salinity. Also, significant differences for OY were found between plants subjected to water containing $\mathrm{K}\left(\mathrm{S}_{5}\right)$ and those subjected to water containing $\mathrm{Na}\left(\mathrm{S}_{2}\right), \mathrm{Ca}\left(\mathrm{S}_{3}\right), \mathrm{Na}+\mathrm{Ca}\left(\mathrm{S}_{4}\right)$ and $\mathrm{Na}+\mathrm{Ca}+\mathrm{Mg}$ $\left(\mathrm{S}_{6}\right)$. Significant influence $(\mathrm{p}<0.05)$ on $\mathrm{OY}$ was observed in plants irrigated using water with $\mathrm{ECw}$ of $0.6 \mathrm{dS} \mathrm{m} \mathrm{m}^{-1}$ compared with those under $4.5 \mathrm{dS} \mathrm{m} \mathrm{m}^{-1}$, according to the analysis of variance of the studied contrasts. The highest OY was observed in plants under low-salinity water $\left(0.6 \mathrm{dS} \mathrm{m}^{-1}\right)$, exceeding the mean value in $49.68 \mathrm{~g}$ plant $^{-1}$, in relation to those irrigated with ECw of $4.5 \mathrm{dS} \mathrm{m}^{-1}$ (Table 2).
Still according to Table 2, OY in $\mathrm{S}_{2}$ was $11.06 \mathrm{~g} \mathrm{plant}^{-1}$ higher than in $S_{5}$. Plants in $S_{5}$ showed a decrease of $3.39 \mathrm{~g}$ plant $^{-1}$ in OY, compared with those under different types of cations $\left(\mathrm{S}_{2} ; \mathrm{S}_{3} ; \mathrm{S}_{4}\right.$ and $\left.\mathrm{S}_{6}\right)$. In general, among the studied cations, a lower $\mathrm{OY}$ was observed in plants irrigated with water containing $\mathrm{K}\left(\mathrm{S}_{5}\right)$. Although this result corroborates the data obtained for the oil content in the seeds (Fig 6A), it is difficult to explain when data of gas exchange and growth variables are taken into account, since plants irrigated with water containing $\mathrm{K}\left(\mathrm{S}_{5}\right)$ showed the highest values for these variables.

Considering that $\mathrm{OY}$ is obtained by multiplying the oil content by the mass of seeds, the mass of seeds in the $S_{5}$ treatment was 20 times lower than in the other treatments $\mathrm{S}_{2} ; \mathrm{S}_{3} ; \mathrm{S}_{4}$ and $\mathrm{S}_{6}$. Thus, this expressive decrease in OY for plants in $\mathrm{S}_{5}$ may be attributed to the fact that $\mathrm{K}^{+}$is absorbed in amounts higher than the necessary, so called "luxury consumption". Under these conditions, the excess of $\mathrm{K}^{+}$may have interfered negatively with the absorption of the other cations by the crops, especially those competing for the same absorption sites in root tissues (Meurer, 2006), inhibiting the absorption of $\mathrm{Ca}^{2+}$ and $\mathrm{Mg}^{2+}$ (Marschner,1995). Therefore, under $\mathrm{Ca}^{2+}$ deficiency, flowering and yield were severely affected, because pollen tube formation and pollen grain germination depend on the presence of $\mathrm{Ca}^{+2}$ (Beyoung, 1965).

\section{Materials and Methods}

\section{Localization, experimental procedure, treatments and plant material}

The experiment was carried out in a greenhouse using drainage lysimeters from November 2013 to February 2014, at the Center of Technology and Natural Resources of the Federal University of Campina Grande (CTRN/UFCG), located in the municipality of Campina Grande-Paraíba, Brazil $\left(07^{\circ} 15^{\prime} 18^{\prime \prime} \mathrm{S}\right.$; $35^{\circ} 52^{\prime} 28^{\prime \prime} \mathrm{W}$; $\left.550 \mathrm{~m}\right)$. The treatments consisted of six types of salinity $\left(\mathrm{S}_{1}-\mathrm{Control} ; \mathrm{S}_{2}-\mathrm{Na}^{+} ; \mathrm{S}_{3}-\right.$ $\mathrm{Ca}^{2+} ; \mathrm{S}_{4}-\mathrm{Na}^{+}+\mathrm{Ca}^{2+} ; \mathrm{S}_{5}-\mathrm{K}^{+}$and $\left.\mathrm{S}_{6}-\mathrm{Na}^{+}+\mathrm{Ca}^{2+}+\mathrm{Mg}^{2+}\right)$, maintaining the proportions of 1:1 and 7:2:1 for $\mathrm{Na}+\mathrm{Ca}$ and $\mathrm{Na}+\mathrm{Ca}+\mathrm{Mg}$, respectively. Plants in the control treatment $\left(\mathrm{S}_{1}\right)$ were irrigated using water with electrical conductivity $(\mathrm{ECw})$ of $0.6 \mathrm{dS} \mathrm{m}^{-1}$, while the other treatments $\left(\mathrm{S}_{2} ; \mathrm{S}_{3} ; \mathrm{S}_{4} ; \mathrm{S}_{5}\right.$ and $\mathrm{S}_{6}$ ) received water of $\mathrm{ECw}=4.5 \mathrm{dS} \mathrm{m} \mathrm{m}^{-1}$, prepared with chloride salts of different cations (Table 3 ). The experiment was set in a randomized block design with six treatments and four replicates, totaling 24 experimental plots, each one with five plants. The castor bean cultivar 'BRS Energia' was used in the experiment, for its strong genetic material, precocity (cycle from 120 to 150 days), short size, semi-indehiscent fruits, average oil content of $48 \%$ in the seeds and average yield of 1,800 $\mathrm{kg} \mathrm{ha}^{-1}$ (Silva et al., 2009).]

\section{Establishment and management of the experiment}

Plants were cultivated in 100-L drainage lysimeters (height $=$ $50 \mathrm{~cm}$; bottom diameter $=30 \mathrm{~cm}$; top diameter $=33 \mathrm{~cm}$ ), perforated at the bottom, where a drain of $4 \mathrm{~mm}$ of diameter was installed to allow drainage. The tip of the drain inside the lysimeter was involved in a nonwoven geotextile (Bidim OP 30 ) in order to avoid obstruction by soil material and, outside the lysimeter, a plastic recipient was placed under the drain, in order to collect the drained water and estimate water consumption. The lysimeters were filled with a $2-\mathrm{kg}$ layer of crushed stone, followed by $54 \mathrm{~kg}$ of soil material (clod-free and homogenized) and $76 \mathrm{~kg}$ of the same soil with humus in 
order to achieve $1 \%$ of organic matter in the entire soil mass. The first $10 \mathrm{~cm}$ of each lysimeter remained free in order to facilitate irrigation. The soil material used in the study was collected from the A horizon (0-30 cm layer) of an Ultisol, from the district of São José da Mata (Campina Grande, Paraíba). Before the experiment, the soil was sampled for chemical and hydro-physical characterization (Table 4) at the Laboratory of Irrigation and Salinity of the CTRN/UFCG, according to the methodology proposed by Claessen (1997). Based on the soil analysis, the acidity was corrected using $49.25 \mathrm{~g}$ of dolomitic limestone in each lysimeter $(130 \mathrm{~kg}$ of soil), to neutralize $\mathrm{Al}^{3+}$ and increase the contents of $\mathrm{Ca}^{2+}$ and $\mathrm{Mg}^{2+}$ to the level of $70 \%$. After liming, the soil showed the following chemical characteristics: $\mathrm{Ca}^{2+}=1.14 \mathrm{cmol}_{\mathrm{c}} \mathrm{kg}^{-1}$; $\mathrm{Mg}^{2+}=1.36 \mathrm{cmol}_{\mathrm{c}} \mathrm{kg}^{-1} ; \mathrm{Na}^{+}=0.30 \mathrm{cmol}_{\mathrm{c}} \mathrm{kg}^{-1} ; \mathrm{K}^{+}=0.14$ $\mathrm{cmol}_{\mathrm{c}} \mathrm{kg}^{-1} ; \mathrm{H}^{+}=0.11 \mathrm{cmol}_{\mathrm{c}} \mathrm{kg}^{-1} ; \mathrm{CEC}=3.05 \mathrm{cmol}_{\mathrm{c}} \mathrm{kg}^{-1}$; Organic matter $=1.08 \mathrm{dag} \mathrm{kg}^{-1} ; \mathrm{P}=47.80 \mathrm{mg} \mathrm{kg}{ }^{-1} ; \mathrm{pH}$ in water $(1: 2.5)=6.42$ and $E C s e=0.20 \mathrm{dS} \mathrm{m}^{-1}$. Different irrigation waters were obtained by the dissolution of sodium, calcium, magnesium and potassium chlorides ( $99 \%$ purity), according to the treatments, in tap water. The amounts were determined taking into consideration the relation between $\mathrm{ECw}$ and salt concentration $\left(10 * \mathrm{mmol}_{\mathrm{c}} \mathrm{L}^{-1}=1 \mathrm{dS} \mathrm{\textrm {m } ^ { - 1 } )}\right.$ proposed by Richards (1954). After preparation and ECw calibration, using a portable conductivity meter, the waters were stored in plastic recipients, adequately protected in order to avoid evaporation. Before seeding, the volume of water necessary to reach field capacity was added to the soil, according to the treatments. After field capacity was achieved, ten seeds of the castor bean cultivar 'BRS Energia' were equidistantly planted in each lysimeter at a depth of 2 $\mathrm{cm}$. At 10 days after seeding (DAS), thinning was performed in order to leave only one plant per lysimeter. After seeding, the soil was kept close to field capacity by daily irrigations in each lysimeter, according to the treatments, and the volume applied was determined based on crop water demand, estimated by the water balance: volume of water applied minus volume of water drained in the previous irrigation, plus a leaching fraction of 0.10 , according to previous studies (Nobre et al., 2013; Lima et al., 2014a). Fertilization with N, $\mathrm{K}$ and $\mathrm{P}$ was performed according to Novais et al. (1991), using $40.62 \mathrm{~g}$ of potassium nitrate and $75 \mathrm{~g}$ of monoammonium phosphate, which was equivalent to 100 , 150 and $300 \mathrm{mg} \mathrm{kg}^{-1}$ of soil of $\mathrm{N}, \mathrm{K}_{2} \mathrm{O}$ and $\mathrm{P}_{2} \mathrm{O}_{5}$, respectively. Fertilizers were applied as topdressing, in four applications through fertigation, at intervals of ten days, with the first one at 15 DAS. In order to avoid any possible deficiency of micronutrients, foliar application of $2.5 \mathrm{~g} \mathrm{~L}^{-1}$ of Ubyfol [ $\left(\mathrm{N}(15 \%) ; \mathrm{P}_{2} \mathrm{O}_{5}(15 \%) ; \mathrm{K}_{2} \mathrm{O}(15 \%) ; \mathrm{Ca}(1 \%) ; \mathrm{Mg}\right.$ (1.4\%); S (2.7\%); Zn (0.5\%); B (0.05\%); Fe (0.5\%); Mn $(0.05 \%) ; \mathrm{Cu}(0.5 \%)$; Mo $(0.02 \%)]$ was performed at 30 and 60 DAS. The cultural practices during the experiment consisted of weekly manual weeding, superficial soil scarification and staking, after plants reached the flowering stage, in order to avoid lodging. In addition, $5.4 \mathrm{~g} \mathrm{~L}^{-1}$ of insecticides, $7.0 \mathrm{~g} \mathrm{~L}^{-1}$ of fungicide and $3.5 \mathrm{~g} \mathrm{~L}^{-1}$ of acaricide, from the Neonicotinamid, Triazole and Abamectin chemical groups, respectively, were applied.

\section{Traits measured}

The effects of the treatments on castor bean physiology were measured at 80 DAS in the fruiting stage, through stomatal conductance $(g s)$, transpiration $(E), \mathrm{CO}_{2}$ assimilation rate $(A)$, internal $\mathrm{CO}_{2}$ concentration $(\mathrm{Ci})$, intrinsic water use efficiency (WUE) and instantaneous carboxylation efficiency (EICI).
Plant growth was evaluated through plant height $(\mathrm{PH})$, stem diameter (SD), number of leaves (NL) and leaf area (LA).

Racemes were manually harvested from 70 to 100 DAS. Harvest was performed when approximately $90 \%$ of the fruits of each raceme reached physiological maturation, and the drying was completed by sun exposure. Castor bean production was evaluated through the oil content (OC) and oil yield (OY) from the seeds of the primary raceme. Stomatal conductance, transpiration, $\mathrm{CO}_{2}$ assimilation rate and internal $\mathrm{CO}_{2}$ concentration were evaluated in the third leaf from the plant apex, using the portable device for photosynthesis measurements "LCPro+" (ADC BioScientific Ltda.). Using these data, the water use efficiency (WUE) $(A / E)$ and instantaneous carboxylation efficiency $(A / C i)$ were quantified (Jaimez et al., 2005). PH was measured from the plant base to the apical meristem. SD was measured $5 \mathrm{~cm}$ distant from the plant base. For NL, only the leaves with minimum length of $3 \mathrm{~cm}$ and at least $50 \%$ of photosynthetically active leaf area were considered. LA was obtained by measuring the length of the midrib of all the leaves in the plants, based on the methodology described by Severino et al. (2005), according to Eq. 1:

$\mathrm{LA}=\Sigma 0.26622 \times \mathrm{P}^{2.4248}$

where:

LA - total leaf area per plant $\left(\mathrm{cm}^{2}\right)$,

$\mathrm{P}$ - length of leaf midrib $(\mathrm{cm})$.

After seeds were dried, processed and had their water content corrected to $10 \%$, the oil content was determined by nondestructive method, using a nuclear magnetic resonance (NMR) spectrometer ( $\mathrm{H}^{1}$ Oxford MQA 7005), at the Advanced Chemical Technology Laboratory of Embrapa Cotton, in Campina Grande-PB (American Oil Chemists' Society, 2000). Oil yield per plant was determined using data of oil content and mass of seeds.

\section{Statistical analysis}

The results were subjected to analysis of variance by F-test; when significant, the means were compared by Tukey's test and contrasts ( $\hat{y}$ ) between treatment means (at 0.05 probability level) were performed using the software SISVAR-ESAL (Ferreira, 2000 ). For the comparison between treatments, the standard error was calculated for each mean. The contrasts were defined as follows: $\hat{y}_{1}\left(S_{1}\right.$ vs $\left.\mathrm{S}_{2} ; \mathrm{S}_{3} ; \mathrm{S}_{4} ; \mathrm{S}_{5} ; \mathrm{S}_{6}\right), \hat{\mathrm{y}}_{2}\left(\mathrm{~S}_{2}\right.$ vs $\left.\mathrm{S}_{3}\right), \hat{\mathrm{y}}_{3}\left(\mathrm{~S}_{2}\right.$ vs $\left.\mathrm{S}_{6}\right), \hat{\mathrm{y}}_{4}\left(\mathrm{~S}_{2}\right.$ vs $\left.\mathrm{S}_{5}\right)$ and $\hat{\mathrm{y}}_{5}\left(\mathrm{~S}_{5}\right.$ vs $\left.\mathrm{S}_{2} ; \mathrm{S}_{3} ; \mathrm{S}_{4} ; \mathrm{S}_{6}\right)$.

\section{Conclusions}

Gas exchanges, growth and oil yield of the castor bean cultivar 'BRS Energia' are more affected by the variation of electrical conductivity in the irrigation water than by its cationic nature; the deleterious effect of saline stress on gas exchange, growth, oil content and oil yield of castor bean varies with the type of cation present in the irrigation water; among the studied ions, potassium promotes the highest values of gas exchange and growth variables; oil yield is the most sensitive variable to the effects of irrigation water salinity and cationic nature; the cultivar 'BRS Energia' is more sensitive to the salinity caused by potassium ions in the irrigation water during the flowering and fruiting stages.

\section{Acknowledgements}

The authors thank the National Council for Scientific and Technological Development (CNPq), the National Institute of 
Science and Technology in Salinity (INCTSal) and the Coordination for the Improvement of Higher Education Personnel (CAPES) for the financial support and grant of the scholarship.

\section{References}

Alves AN, Gheyi HR, Uyeda CA, Soares FAL, Nobre RG, Cardoso JAF (2012) Uso de águas salinas e adubação nitrogenada no cultivo da mamoneira BRS-Energia. Rev Bras de Agric Irrig. 6:151-163.

Alves MS, Soares TM, Silva LT, Fernandes JP, Oliveira MLA, Paz VPS (2011) Estratégias de uso de água salobra na produção de alface em hidroponia NFT. Rev Bras Eng Agríc Ambient. 15:491-498.

American Oil Chemists' Society. Official methods and recommended practices of the AOCS. 5.ed. Champaign: AOCS, 2000.

Amorim Neto M da S, Araújo AE de, Beltrão NE de M (2001) Clima e solo. In: Azevedo DMP de, Lima EF. (ed.). O agronegócio da mamona no Brasil. Brasilia: Embrapa Informação Tecnológica, 2001. cap. 3, p.63-76.

Ashraf M, Harris PJC (2004) Potential biochemical indicators of salinity tolerance in plants. Plant Sci. 166:3-16.

Bernardi ACC, Oka SH, Souza GB de (2010) Comparação de técnicas analíticas para a extração de potássio de amostras de tecido vegetal com água e soluções ácidas concentradas e diluída. Eclet Quím. 35:45-49.

Beyoung HK (1965) The effects of calcium on pollen germination. J Am Soc Hortic Sci. 86:818-823.

Campos VB, Cavalcante LF, Rodolfo Júnior F, Sousa GG, Mota JK (2009) Crescimento inicial da mamoneira em resposta à salinidade e biofertilizante bovino. Rev Magist. 21:41-47.

Claessen, M.E.C. (Org.) (1997) Manual de métodos de análise de solo. 2.ed. rev. atual. Rio de Janeiro: Embrapa-CNPS. 212p. (Embrapa-CNPS. Documentos, 1).

Ferreira DF (2003) SISVAR 4,6 - programa de análise estatística. Lavras: Universidade Federal de Lavras. 1 CDROM.

Flowers TJ (2004) Improving crop salt tolerance. J Exp Bot. 55:307-319.

Gurgel MT, Uyeda CA, Gheyi HR, Oliveira FHT de, Fernandes PD, Silva FV da (2010) Crescimento de meloeiro sob estresse salino e doses de potássio. Rev Bras Eng Agríc Ambient. 14:310.

Habermann G, Machado EC, Rodrigues JD, Medina CL (2003) $\mathrm{CO}_{2}$ assimilation, photosynthetic light response curves, and water relations of 'Pêra' sweet orange plants infected with Xylella fastidious. Braz J Plant Physiol. 15:79-87.

Jaimez RE, Rada F, Garcia-Núñez C, Azócar A (2005) Seasonal variations in leaf gas exchange of platain cv. Hartón (Musa $\mathrm{AAB}$ ) under different soil water conditions in a humid tropical region. Sci Hort. 104:79-89.

Lima GS de, Nobre RG, Gheyi HR, Soares LA dos A, Silva SS da (2014a) Respostas morfofisiológicas da mamoneira, em função da salinidade da água de irrigação e adubação nitrogenada. Irriga. 19:130-136.

Lima GS, Nobre RG, Gheyi HR, Soares LAA, Silva AO (2014b) Physiology, growth and yield of castor bean under salt stress and nitrogen doses in phenophases. Idesia. 32:91-99.

Machado DFSP, Machado EC, Machado RS, Ribeiro RV (2010) Efeito da baixa temperatura noturna e do porta-enxerto na variação diurna das trocas gasosas e na atividade fotoquímica de laranjeira 'Valência'. Rev Bras Frutic. 32:351-359.

Machado EC, Schmidti PT, Medina CL, Ribeiro RV (2005) Respostas da fotossíntese de três espécies de citros a fatores ambientais. Pesq Agropec Bras. 40:1161- 1170.

Marschner, H. Mineral nutrition of higher plants. London: Academic Press, 1995. 889p.

Medeiros J F de, Lisboa R de A, Oliveira M de (2003) Caracterização das águas subterrâneas usadas para irrigação na área produtora de melão da Chapada do Apodi. Rev Bras Eng Agríc Ambient. 7:469-472.

Meurer EJ (2006) Potássio. In: Fernandes MS (ed.) Nutrição mineral de plantas. Viçosa: Sociedade Brasileira de Ciência do Solo. p.281-299.

Nobre RG, Gheyi HR, Soares FAL, Cardoso JAF (2011) Produção de girassol sob estresse salino e adubação nitrogenada. Rev Bras Ciênc Solo. 35:929-937.

Nobre RG, Lima GS de, Gheyi HR, Lourenço GS, Soares LAA (2013) Emergência, crescimento e produção da mamoneira sob estresse salino e adubação nitrogenada. Rev Ciênc Agron. 44:76-85.

Novais RF, Neves JCL, Barros NF (1991) Ensaio em ambiente controlado. In: Oliveira AJ (ed.) Métodos de pesquisa em fertilidade do solo. Brasília: Embrapa-SEA. p.189-253.

Oliveira Filho AF de, Oliveira $\mathrm{F}$ de A de, Medeiros JF de, Mesquita,T de O, Zonta E (2010) Crescimento de cultivares de mamoneira sob doses de torta de mamona. Rev Verde de Agroec e Desenvolv Sustent. 5:18-24.

Ribeiro RV, Machado EC, Santos MG, Oliveira RF (2009) Photosynthesis and water relations of well-watered orange plants as affected by winter and summer conditions. Photosynthetica. 47:215-222.

Ribeiro S, Chaves LHG, Guerra HOC, Gheyi HR, Lacerda RD de (2009) Resposta da mamoneira cultivar BRS-188 Paraguaçu à aplicação de nitrogênio, fósforo e potássio. Rev Ciênc Agron. 40:465-473.

Richards LA (1954) Diagnosis and improvement of saline and alkali soils. Washington: U. S. Department of Agriculture. 160p. (USDA, Agriculture Handbook, 60).

Santos B dos, Ferreira PA, Oliveira FG de, Batista RO, Costa AC, Cano MAO (2012) Produção e parâmetros fisiológicos do amendoim em função do estresse salino. Idesia. 30:69-74.

Santos JB dos, Santos DB dos, Azevedo CAV de, Rebequi AM, Cavalcante LF, Cavalcante IHL (2013) Comportamento morfofisiológico da mamoneira BRS Energia submetida à irrigação com água salina. Rev Bras Eng Agríc Ambient. 17:145-1522.

Severino, L. S., Vale, L. S., Cardoso, G. D., Beltrão, N. E. de M., Santos, J. W. dos. Método para determinação da área foliar da mamoneira. Campina Grande: Embrapa - CNPA, 2005. 20p. (Boletim de Pesquisa e Desenvolvimento, 55).

Silva SMS, Gheyi HR, Beltrão NE de M, Santos JW dos, Soares FAL (2009) Dotações hídricas em densidades de plantas na cultura da mamoneira cv. BRS Energia. Rev Bras de Ciênc Agr. 4:338-348.

Soares LAA, Nobre RG, Gheyi HR, Lima GS, Silva AO, Soares SS (2012) Componentes de crescimento da mamoneira cultivada com águas salinas e doses de nitrogênio. Irriga. Edição Especial. 40-54.

Taiz L, Zeiger E. Fisiologia vegetal. 5. ed. Porto Alegre: Artmed, 2013.819p

Tezara W, Marín O, Rengifo E, Martinez D, Herrera A (2005) Photosynthesis and photoinhibition in two xerophytic shrubs during drought. Photosynthetica. 43:37-45. 